\title{
The Correlation between Environmental Sanitation and Stunting Case in Pidie District
}

\author{
Herman Fithra $^{\mathrm{a}}$, Deassy Siska ${ }^{\mathrm{b}}$ \\ ${ }^{a}$ Civil Engineering, Universitas Malikussaleh, Irian Street no. 7 Bukit Indah Campus, Lhokseumawe, 24352, Indonesia \\ E-mail:hfithra@unimal.ac.id \\ ${ }^{b}$ Engineering Faculty, Universitas Malikussaleh, Irian Street no. 7 Bukit Indah Campus, Lhokseumawe, 24352, Indonesia \\ E-mail: deassy@unimal.ac.id
}

\begin{abstract}
Environmental sanitation is a significant problem for mapping environmental health conditions. There are several districts in Aceh Province that are under stunting assessment. Stunting has been a national problem now. One of the causes of stunted growth (Stunting) is low sanitation in an area. To solve this problem, it is essential to have collaboration between the central, regional, subdistrict, and other related institutions. The Implementation Process This research was marked by taking stunting and sanitation survey data in 10 Subdistricts in Pidie District for four months, starting in August 2018 to December 2018. The purpose of this study was to determine the extent of environmental sanitation analysis that could affect nutritional status in conditions dwarf in the Aceh Pidie region. The design of this study was cross-sectional. The population in this study was a population sample that was taken randomly in 10 subdistricts in Pidie district. The total sample was 90 respondents, and a complete sample was used. The results showed that there was a relationship between environmental sanitation mapping and the nutritional status of children under five in the Aceh Pidie region. Thus, it can be concluded that there is positive verification of the state of poor sanitation environment in the nutritional status of children in Pidie district, Aceh Province. Based on the results of this study, Pidie regency regional planning is expected to be more focused on environmental sanitation based on public health.
\end{abstract}

Keywords - stunting; sanitation; environment; regional planning.

\section{INTRODUCTION}

The high rate of poverty caused by the high rural unemployment rate has an impact on the high number of poor nutrition and stunting cases. Based on the data from Indonesia's National Planning Agency, the number of poor people in the subdistricts in Indonesia is 27.7 million people, and 10.2 million of them live around and in forest areas [1]. To build a good understanding of the development, measurement, and measurement of poverty findings, considered with inequality and public consumption, and the government's strategy to overcome poverty in Indonesia [2]. The Ministry of PPN/Bappenas held a media discussion entitled "Dissecting the Current Poverty Rate" in PPN Minister/Bappenas Head Room, Bappenas Building, Thursday (7/19) was quoted in the discussion PPN Minister/Bappenas Head explained the national poverty rate in March 2018, amounting to 9.82 percent or expanded by 25.9 million people Indonesia. It has just been released by the Central Statistics Agency [2] is the lowest poverty rate. value since the New Order period. "The single-digit poverty figure has been broken, meaning that the number of poor people in March 2018 decreased 1.82 million or 0.82 percentage points compared to March 2017.

Indonesia still faces nutritional problems that have an impact serious about the Quality of Human Resources (HR). One of the Nutritional problems that are a significant concern at this time is still the height of a toddler is short (Stunting) [3] At present, Indonesia is faced with Double Nutrition Burden or often called Double Burden, which means when we are still working hard to overcome the problem of deficiency, Nutrition such as thin, Stunting, and anemia [4](citation required). However, now, the same must face the problem of excess Nutrition or obesity.

Dwarf children that occur in Indonesia are not only experienced by households/family's poor and disadvantaged because households/families also experience stunting, not poor / who are above $40 \%$ level of social and economic welfare. Such that illustrated in the graph below, the condition of stunting children is also experienced by families/households who are not poor [5]. The access of residents to the residential infrastructure and facilities related to the health, environment, socio-cultural education, and poverty. The more natural access to the infrastructure and 
wastewater facilities and the better understanding of hygienic, the smaller the number of cases of the spread of diseases. Aceh is one of the provinces which consists of 23 districts, which are included in the spotlight of the stunting region in Indonesia [6]. Pidie District, Central Aceh District, and East Aceh District are the regions that have the highest value for the number of data on cases of stunting children. Aceh Province is one of the provinces in Indonesia that has low access to sanitation and needs to be improved. Aceh Province is one of the areas that received attention in sanitation development in the 2000s, especially those related to efforts to implement clean water programs. Starting from high stunting values from three districts in Aceh province, a study was conducted on the relationship between stunting rates and sanitation patterns in Pidie district. Hopefully, this research can be a reference for local governments. The study of mapping research on priority areas to improve sanitation accessibility in Aceh Province was intended as a contribution to the development of a strategic plan for Sanitation Development in Aceh Province. The specific objective of this research is to determine the priority areas of districts/cities in improving sanitation access.

The Picture in Fig 1 shows the condition of Indonesia's household with low sanitation access [7]. The area detected by the coverage of little sanitation access is some parts of Sumatera (some areas located in ACEH which becomes the object of this research), Kalimantan, Sulawesi, Southeas Nusa and most of the territory of Papua. The image also shows the correlation between the number of stunting cases.

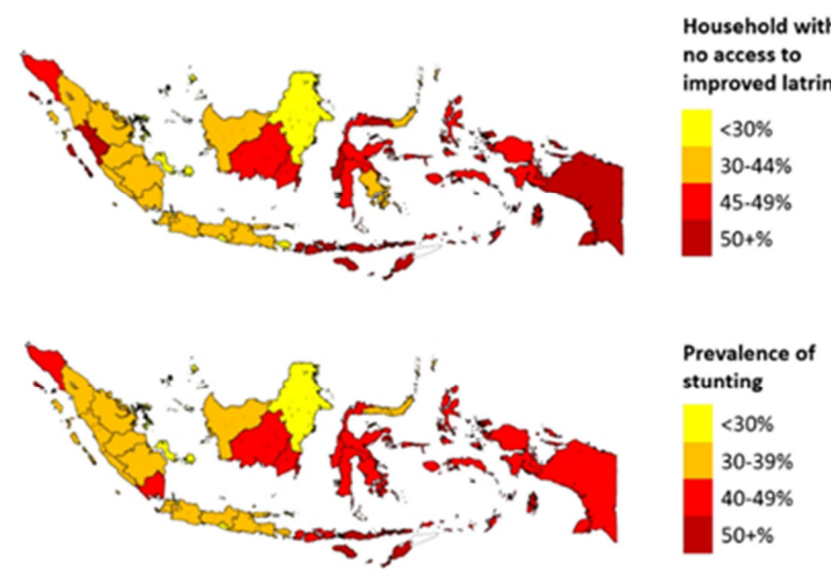

Fig. 1 The condition of Indonesia's households with low access to sanitation and a very high percentage of Stunting cases.

\section{MATERIALS AND METHOD}

The research design used was cross-sectional [8] (citation required). In this study, the cause or risk variable and the consequences or cases that occur in the object of research are measured and collected simultaneously, just once or once at the same time or time. Research has found that sanitation infrastructure is cultured or is shaped by national-level cultural preferences [9]. The study expands on this past work to identify causal pathways showing combinations of cultural dimensions that explain sanitation infrastructure technology choice, including total access to improved sanitation facilities, sewerage connections, and access to onsite treatment technologies.
The dependent variable is the output response. The dependent variable in this study is the nutritional status of infants. The population is all variables that concern the problem that is the object of research. In this study, the population is a random population sample in 10 subdistricts in Pidie District. The population in this study was 9 people per subdistrict. The Sustainable Development Goals are calling for universal access to proper sanitation towards 2030. The Method used in this research:

- Method of data collection: Survey

- Survey Design: Cross-Sectional Study

- Multilevel sampling

- The selection of Village (sub-subdistrict) was by the criteria.

If the number of villages is 5 or less, then 3 village are taken. If the number of villages is 6 or more, then 5 village are taken. Dusun is a village, Desa is sub-district, Kecamatan is a District, and Kabupaten is a regency.

From the selected subdistricts, only 3 households were taken as respondents and the intermittent selection of 3 or 5 households. The survey was conducted in 10 subdistricts in Pidie District in 2018 for 2 months, as shown in table 1.

TABLE I

SANITATION CONDITION DI PIDIE DISTRICT

\begin{tabular}{|l|l|l|}
\hline \multicolumn{2}{|c|}{ Sanitation Condition in Pidie District } & Frequency (\%) \\
\hline $\begin{array}{l}\text { The percentage } \\
\text { of having a } \\
\text { toilet at home }\end{array}$ & $\begin{array}{l}\text { Ara Subdistrict, } \\
\text { Kembang Tanjong } \\
\text { Subdistrict }\end{array}$ & 30 \\
\cline { 2 - 3 } & $\begin{array}{l}\text { Mesjid Usi, Mutiara } \\
\text { Subdistrict }\end{array}$ & 34 \\
\cline { 2 - 3 } & $\begin{array}{l}\text { Nien, Simpang Tiga } \\
\text { Subdistrict }\end{array}$ & 24 \\
\cline { 2 - 3 } & $\begin{array}{l}\text { Ulee Gunong, Tangse } \\
\text { sub district }\end{array}$ & 10 \\
\cline { 2 - 3 } & Balee Ujong Rimba & 40 \\
\cline { 2 - 3 } & Campli Usi & 60 \\
\cline { 2 - 3 } & Panton Beunot & 16 \\
\cline { 2 - 3 } & Teungoh mangkie & 34 \\
\cline { 2 - 3 } & peunadok & 18 \\
\cline { 2 - 3 } & Meunasah Panah & 15 \\
\hline
\end{tabular}

TABLE II

SURVEY TIMELINE

\begin{tabular}{|c|c|c|c|c|c|c|c|c|c|c|c|c|c|}
\hline \multirow{3}{*}{ No } & \multirow{3}{*}{ Activities } & \multicolumn{12}{|c|}{ Time Schedule (Month) } \\
\hline & & \multicolumn{4}{|c|}{$\begin{array}{l}\text { October (2018) } \\
\text { (Week) }\end{array}$} & \multicolumn{4}{|c|}{$\begin{array}{l}\text { November } \\
\text { 2018) (Week) }\end{array}$} & \multicolumn{4}{|c|}{$\begin{array}{l}\text { December } 2018 \\
\text { (Week) }\end{array}$} \\
\hline & & $\mathrm{I}$ & II & III & IV & $\mathrm{I}$ & II & III & IV & $\mathrm{I}$ & II & III & IV \\
\hline 1 & $\begin{array}{l}\text { Data } \\
\text { Survey }\end{array}$ & & & & & & & & & & & & \\
\hline 2 & $\begin{array}{l}\text { Submission } \\
\text { of Survey } \\
\text { Results }\end{array}$ & & & & & & & & & & & & \\
\hline 3 & $\begin{array}{l}\text { Raw Data } \\
\text { Verification }\end{array}$ & & & & & & & & & & & & \\
\hline 4 & $\begin{array}{l}\text { Survey } \\
\text { Final } \\
\text { Report }\end{array}$ & & & & & & & & & & & & \\
\hline
\end{tabular}

There are some things that we must carry out during observations, namely: 
- Observation was conducted together with the interview

- Observation targets: sanitation condition (latrine, wastewater, clean water, house condition)

- Observing the situation at the respondent's house and the surroundings of selected subdistricts.

\section{RESULT AND DISCUSSION}

This data is based on the recapitulation of respondents' demographic data which includes data on the Frequency Distribution of Respondents Characteristics Based on Environmental Sanitation in Panton Beunot Subdistrict on December 10, 2018, with the following results:

TABLE III

FREQUENCY DISTRIBUTION CHARACTERISTICS OF RESPONDENTS BASED ON SANITATION THE ENVIRONMENT IN PANTON BEUNOT SUBDISTRICT

\begin{tabular}{|l|l|l|}
\hline Environment Sanitation & Frequency (\%) \\
\hline Good & 4 & 12 \\
\hline Enough & 21 & 66 \\
\hline Less & 7 & 22 \\
\hline
\end{tabular}

Based on the data above, most respondents with sufficient environmental sanitation were 21 respondents $(66 \%)$.

Environmental health is essentially an optimal environmental condition or condition, so that it has a positive effect on the realization of optimal health status as well. The scope of environmental health includes housing, sewage disposal, clean water supply, garbage disposal, dirty water disposal (wastewater), and livestock houses (pens). The health status of a community environment depends on the value of community sanitation. If sanitation is clean, then environmental health will be cleaned too. This environmental health has an impact on the high or low stunting rate of an area.

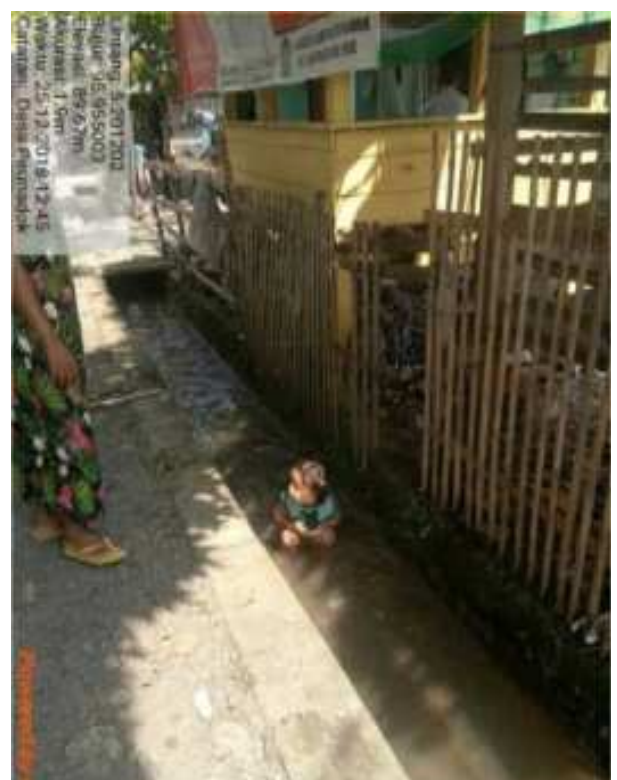

Fig.2 The condition of defecation in the river flow in the subdistrict of Peunadok, Tiro Subdistrict, Pidie District

Several studies related to prioritizing the improvement of sanitation access have been carried out in the Aceh province or other regions. Variables used as the basis for determining priorities are:

- The distance of the spring to the nearest feces shelter;

- Facilities for defecation, which are distinguished by shared facilities and used by other families. For those who are used with other families, they are divided into shared facilities and public facilities.

- The toilet system used by households. The toilet system is categorized into four groups, each of which is a swan neck, plengsengan, which is a gooseneck system, tilted directly into the shelter, then a Cubluk, a toilet located on land and covered

Several pictures are presented several subdistricts in the Pidie region that show the level of poor sanitation conditions such as a child who defecates in the drainage ditch in front of the house because there is no toilet inside the house as in Figure 2

Condition Figure 3 shows the damaged septic tank found behind the houses of residents in the Peunadok subdistrict of the Tiro Truseb sub-district. This damaged septic tank makes residents no longer defecate inside the house but in the river. The conditions of low sanitation like this have an impact on the stunting rate.

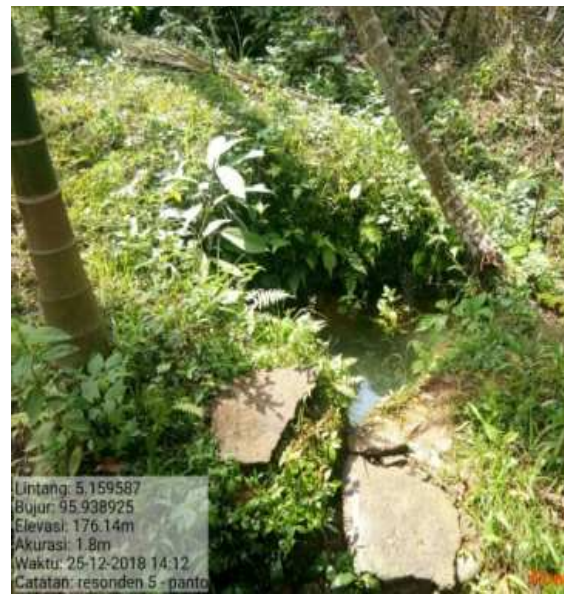

Fig. 3 Existing conditions of untreated septic tank discharge in Panton Beunot subdistrict, Tiro Sub-district, Pidie district

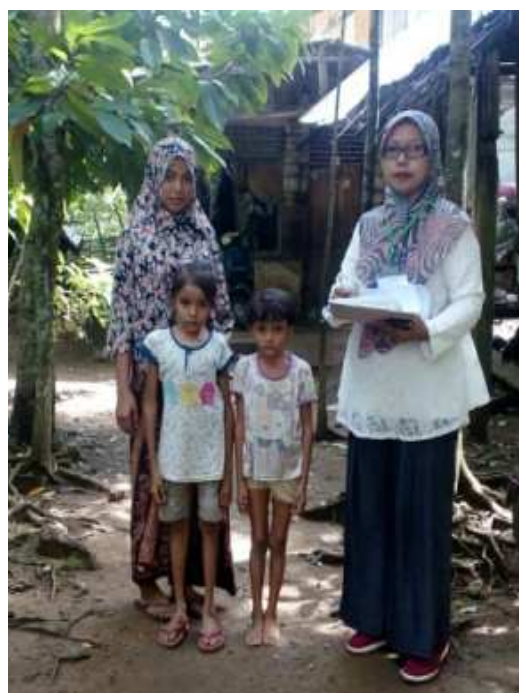

Fig. 4 take pictures with children affected by stunting cases in Balee Ujong Rimba subdistrict, Mutiara Sub-district, Pidie District 
Stunting is one of the significant causes of morbidity and mortality among under-five children. It is used to assess the nutritional status of children by measuring their Length/height and age.

Fig 2 to 4 shows Some real conditions related to Stunting and sanitation in several subdistricts in Pidie District. In Pidie District, there are ten subdistricts taken as research samples. From each subdistrict, three villages were selected as samples, and 3 families were selected for survey targets.

The Health Service of Aceh province recommended these subdistricts as they have the highest number of stunting cases in Pidie district. The highest stunting rate is due to a low public understanding of the importance of sanitation. $90 \%$ of the house does not have a toilet in the house. The adult subdistricts still practice open defecation in the river, while children in the ditch in front of the house (e.g., Fig 2).

Fig. 3 is one of the big water drains that is in the small river stream (local people call it Lueng). Almost all subdistricts make this location an open defecation area, as well as a Septic tank. Dirt directly contaminated with soil.

Among the 9 (nine) randomly selected rural families, many samples were directly related to stunting case, and they have 2 to 3 children under five years old (e.g., Fig.4). The stunting condition is referred to as underweight/ the body weight under the standard of local health service. The local health service has recorded this stunting reference.

The results showed that there was an environmental sanitation effect on the nutritional status of children under five years, which resulted in stunting in Pidie district. This is because nutritional status is influenced not only by environmental sanitation but also by several factors, including lack of awareness of having a toilet at home.

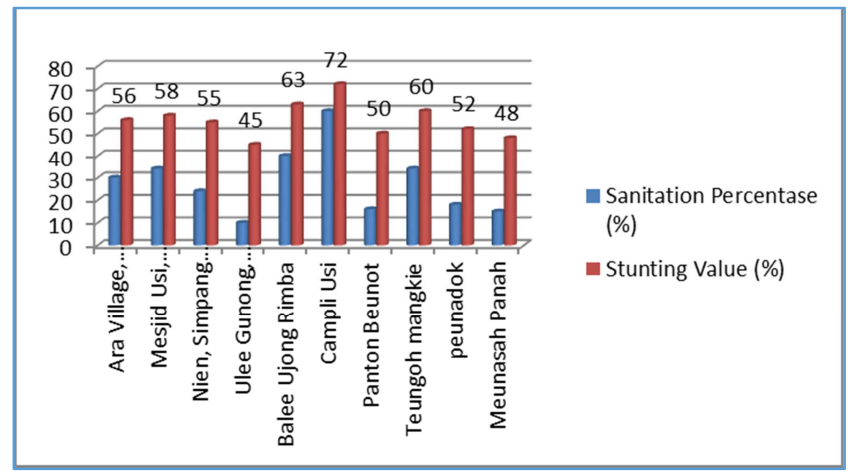

Fig. 5 Sanitation and stunting conditions in 10 subdistricts in Pidie district

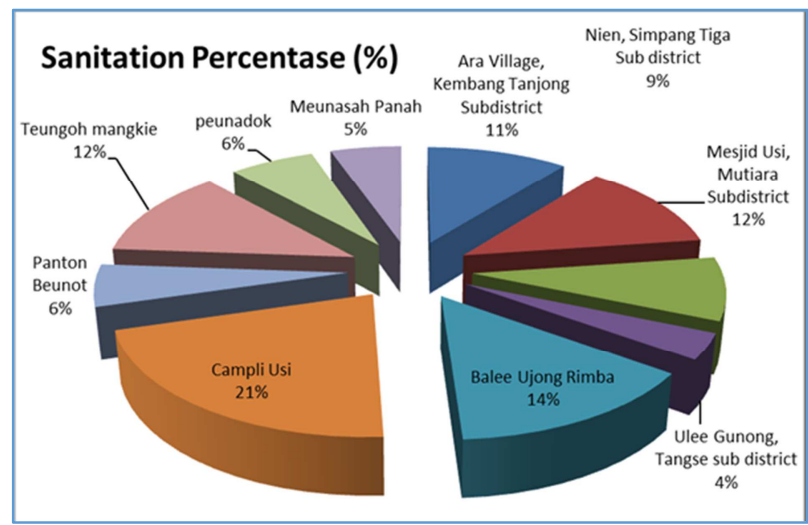

Fig. 6 The results of accumulated calculations and graphs of sanitation conditions are based on survey data from 10 subdistricts in Pidie district
The results showed that the Pidie district needs severe sanitation treatment. Stunting and sanitation have a linear relationship. In the example of 10 subdistricts in Pidie district, it can be seen that high levels of sanitation need increased the stunting rate. Campli USI Subdistrict indicates this condition with open defecation practice resulted in a high stunting rate in the area, as shown above (e.g., Fig 5\&6).

\section{A. Recommendation from Sanitation Design}

1) The individual septic tank technology: It is one of the essential things in a building where it functions as a dirty water treatment plant (domestic wastewater), especially from the toilet or water closet. In contrast, the wastewater from the kitchen and bathroom is processed through infiltration well. The individual toilet can be provided for locations that have the following criteria (e.g., fig.7):

- Residents who have not had a toilet and septic tank as per Indonesian National Standard (SNI) 03-2398-2002

- Population density is less than 50 inhabitants/Ha

- Beneficiaries of approximately 50 households with quality of buildings meet the minimum service standard (SPM)

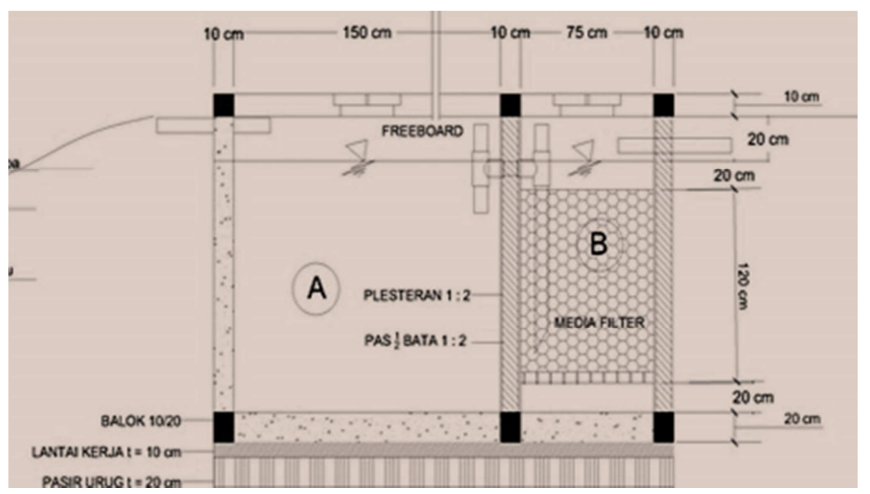

Fig. 7. Individual Septic Tanks (Crested chamber, toilet, septic tank).

The individual toilet component consists of Water Closet and its accessories (procurement/rehabilitation) Toilet building (development/rehabilitation) made of bricks or similar materials, plaster equipped with tiled floors, roof tile, zinc, Alumdex/spandex Control tub with grease trap Twin septic tank, a septic tank equipped with a Filter bio and infiltration area.

2) Communal Septic tank: Communal tank technology option can be implemented for locations that have the following criteria:

- Residents who have not had a toilet and septic tank as per SNI 03-2398-2002

- Population density is less than 50-150 inhabitants/Ha

- The budget of Rp. 300,000,000, - for Rp. 350,000,000, - with the number of beneficiaries of more than 50 households with the quality of buildings meeting minimum service standards and adjusted to the conditions on the ground.

- Each communal septic tank unit at least serves 5 households

3) Combination of Individual \& Communal Septic Tank. 
A communal and individual septic tank technology option can be implemented for locations that have the following criteria (e.g., fig 8):

- For people who do not have a toilet and septic tank as per SNI standard

- Population density is $50-150$ people/Ha

- The budget of IDR. 300,000,000, -with the number of beneficiaries, is of more than 50 households with the quality of the building meets the minimum service standard.

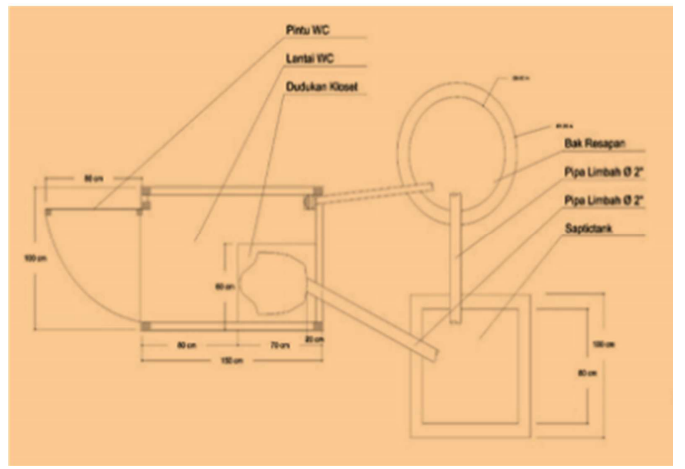

Fig. 8 Combination of Individual \& Communal Septic Tank

This option can be implemented in the location where both individual and communal septic tanks are needed. Stages of primary and secondary data collection in this study, one of which is the survey method. Before conducting a survey, the surveyor must-visit subdistrict officials first, such as the subdistrict head, subdistrict secretary, and the local health office. We must prepare a map of the subdistrict when visiting the subdistrict. So that during the survey, only survey data were asked of respondents. The end of this survey is an analysis based on social mapping, which is like the following example for Nien Subdistrict.

\section{B. Brief Description}

The subdistrict of Nien is a subdistrict with a dense population and is located south of the subdistrict capital of Kembang Tanjong sub-district, Pidie, Aceh Province. Area $=$ 95 Hectares, Total Population $=831$ people $/ 219$ Familys, population density of 4.56 people/Hectares. This subdistrict is located $7 \mathrm{~km}$ to the east of the city of Sigli, the capital of PIDIE Regency, which takes about 15 minutes. The subdistrict of NIEN is Stunting Subdistrict, which is one of 10 Stunting Subdistricts in Pidie district based on Public Health Office data and real data in the subdistrict (Source: Posyandu Cadre), where currently the number of toddler stunting: nine persons by nine families. Poor consist of fortyfive families. The cause of Stunting Toddlers in Nien Subdistrict is malnutrition and contamination of soil and clean water with defecation patterns that are still in the river and on the ground, making the soil polluted.

Coordinate Place: Latitude: 5.33517 Longitude: 95.996313

Population

Total number of subdistricts: 831 people/219 families.

Number of men: 185 people

Number of women: 235 people
Established From 3 Floors

Hamlet of Hikmah $=54$ families

Rahmah Hamlet $=29$ families

Hamlet Sabar $=35$ families

Open Defecation Numbers, stunting, Poor, and

Special Disability / Needs

Total Defecation $=37$ families

Private latrines without processing $=2$ units $/ 2$ families

Cubluk Private Toilet $=60$ Units $/ 81$ families

Total Stunting $=11$ Souls $/ 11$ HHs.

Total MBR $=45$ families.

Total Disability $=6$ people

Average amount of income $=$ Rp. 500,000 / month

Recommended Technology Options: Latrine Rooms and Individual Septic Tanks 37 families and communal septic tanks for 81 families.

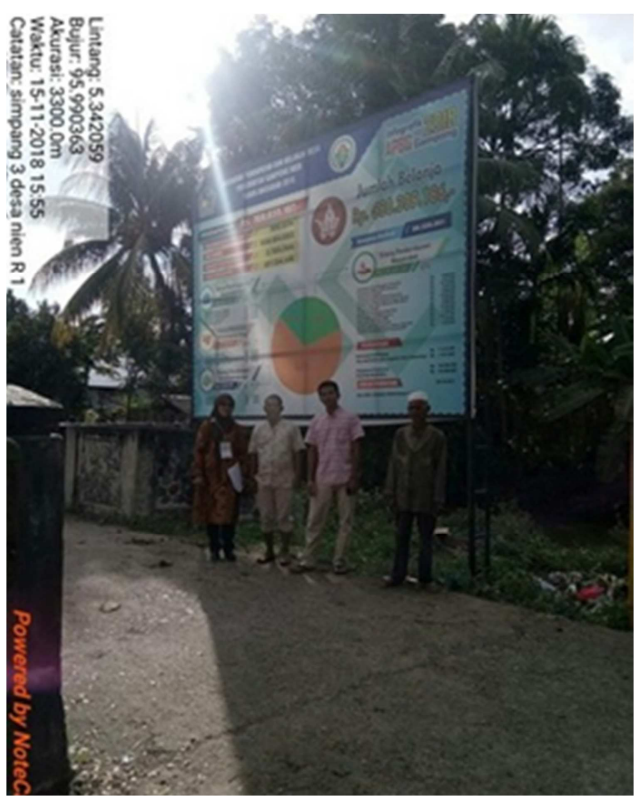

Fig. 9. Survey Team arrived in Nien Subdistrict.

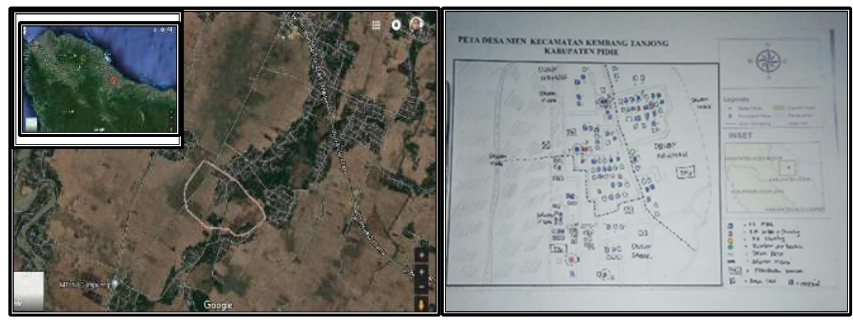

Fig. 10 Nien Subdistrict Map of Kembang District Tanjong

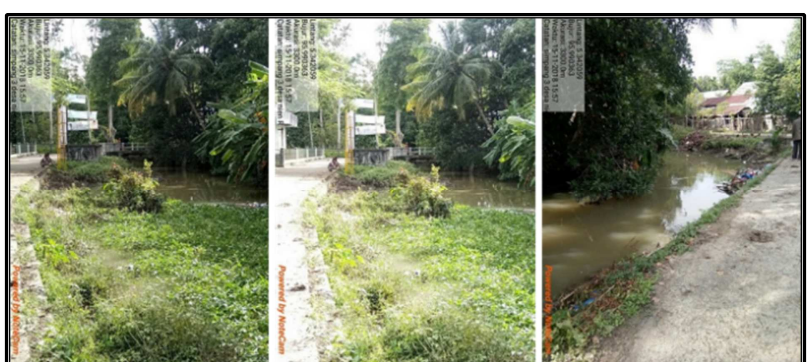

Fig. 11 The condition of the river, which is the place to dispose of large in Nien Subdistrict, Kembang Tanjong, Pidie District, Aceh. 
The Sanitation conditions in Nien subdistrict (fig 11) are not much different from sanitation in other subdistricts in the district of Pidie. Most people still have a culture of defecating in the river because there is no toilet inside the house.

Over a billion people worldwide defecate in the open, with significant consequences for early-life health and human capital accumulation in developing countries. We report a cluster randomized controlled trial of a subdistrict sanitation intervention conducted in rural Maharashtra, India designed to identify an effect of subdistrict sanitation on average child height, an outcome of increasing importance to economists [10]. In the State of The Asan Hamlet, There Are 3 Units of General Toilet. During This Time, All the People Are A Few Parts to Defecate into This public toilet even though should be the queue and the impression (Fig.12).

Figure 12 tells about a toilet that is used together called a public toilet. The state of this toilet is still not perfect. Provision of public toilets is not only a matter of land use but also an essential design and planning concern. This study examines the following questions through an analytical study. (i) What problems do public toilets pose? (ii) What toilet facilities do people require most and most emphasize would affect the way they use land and participate in social life? (iii) How do demands, needs, and expectations around public toilets change depending on gender, age, and ability? We conduct a survey of 300 people in fourteen public restrooms in the city Centre of Ankara, Turkey. According to factor analysis results, public toilets should be potential urban spaces and initial opportunities for sustainable urban developments and liveable cities [11]

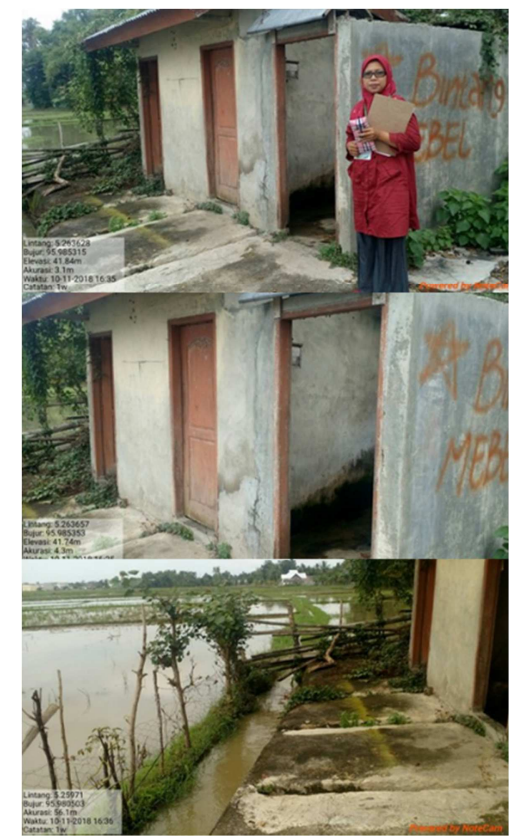

Fig.12 Public toilets used together in the subdistrict

Environmental health at the essence is a condition or optimum environmental condition so that it has a positive effect on the realization of the health status optimum too. Scope of health the environment includes housing, sewage disposal feces, the supply of clean water, garbage disposal, water disposal dirty (wastewater), livestock house (cages), etc. In a journal reference according to Pascale, Stunting and sanitation are described as Stunting leads to deleterious effects on the child's short-term and long-term health, including increased susceptibility to infection and impaired brain development [12].

According to Ni Tengah, Early childhood is often called the golden age that is an active individual with rapid growth and development, so the nutritional needs must be met and balanced [5]. Moreover, this period is susceptible to environmental contact, and more attention is needed especially nutritional adequacy. Nutrition problems that occur in toddlers, especially undernutrition and Stunting, are the impact of the mother's condition/expectant mother during pregnancy, fetal period, toddler, including illness, suffered during childhood. Inadequate Nutrition and Stunting in under-five children may inhibit the development of the children; later, the negative impacts will occur in life, such as intellectual decline, disease susceptibility. The next respondent from Lancang hamlet was named Nelya. He is the mother of a stunting toddler. In a weak economic situation, it is tough for him to build a toilet in his house, so that during this time the condition of defecation is in the Meunasah public toilet (e.g., Fig 12). here are some conditions when the survey team came to interview respondents (e.g., fig 13 to 14 ).

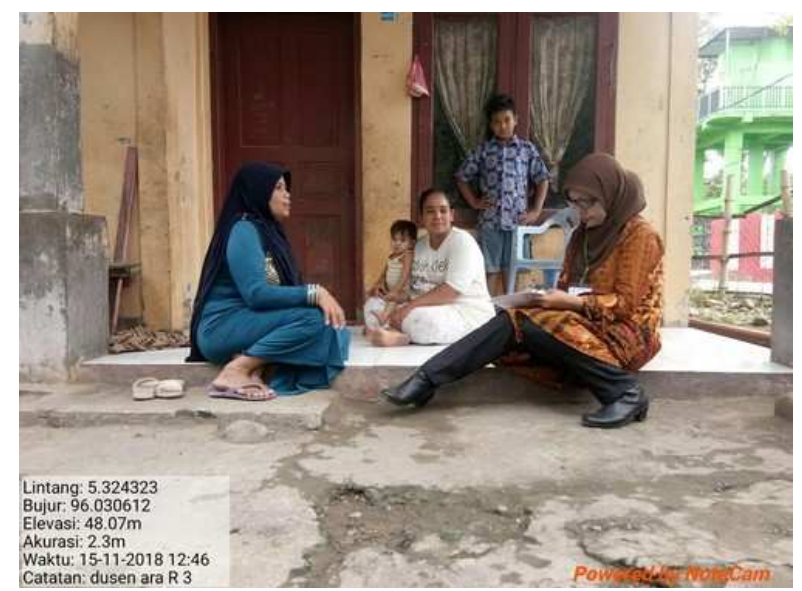

Fig. 13 The condition of the river, which is the place to dispose of large in NIEN Subdistrict, KEMBANG TANJONG Sub District, PIDIE DISTRICT, Aceh.

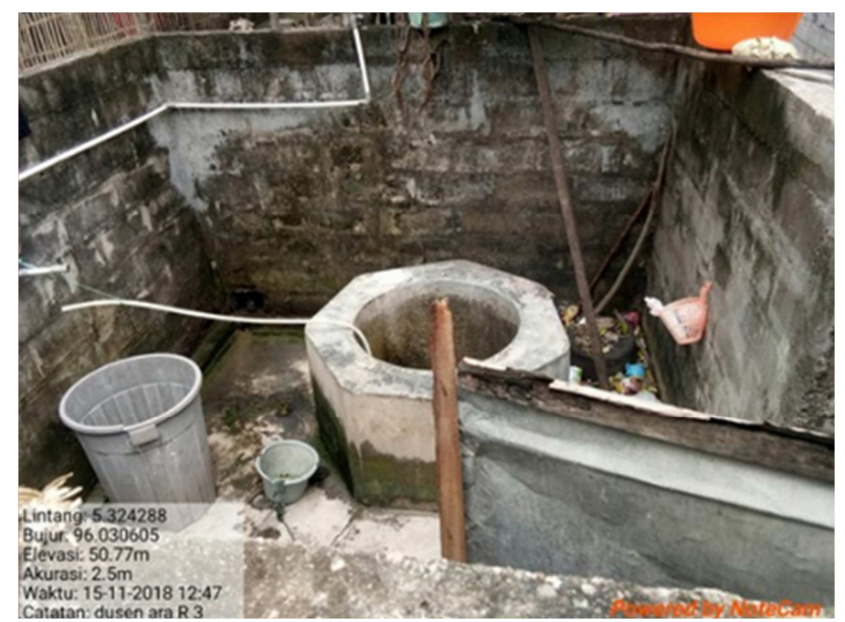

Fig. 14 The condition of sanitation, No WC. 


\section{CONCLUSIONS}

The results of the study showed that there was an effect of environmental sanitation on the nutritional status of children under five, which resulted in stunting in Pidie district. This is because nutritional status is influenced not only by environmental sanitation but also by several factors, including lack of awareness of having a toilet at home. Stunting and sanitation are linearly correlated. In a sample of 10 subdistricts in Pidie district, the level of high sanitation needs will increase the stunting rate. Campli Usi subdistrict showed that this condition with high open defecation patterns resulted in high stunting rates in the area. The total sample was 90 respondents, and total sampling was used. The independent variable is environmental sanitation, and the dependent variable is nutritional status. Data were collected using questionnaires and interviews, then analyzed using linear regression with significance.

\section{ACKNOWLEDGMENT}

We would like to show our gratitude to the Institute for Research and Community Service Unimal (LPPM Unimal) for enabling us to conduct research. Universitas Malikussaleh funded this study.

\section{REFERENCES}

[1] K. PPN, "Rencana Pembangunan Jangka Menengah Nasional," Rencana Pembangunan Jangka Menengah Nasional (2020 - 2024), p. 18, 14 Agustus 2019.

[2] T. Afandi, "https://www.bappenas.go.id," 19 Juli 2018. [Online]. Available:

https://www.bappenas.go.id/files/2815/3309/5355/Siaran_Pers__Membedah_Angka_Kemiskinan_Terkini_Langkah_Strategis_untuk _Terus_Turunkan_Kemiskinan.pdf. [Accessed 11 April 2020].
[3] Awaludin, "[Analisis Bagaimana Mengatasi Permasalahan Stunting Di Indonesia?," UGM Public Health Symposium, vol. Vol 35, no. No, 4 , pp. 1-4, 2019.

[4] M. Dr. drh. Didik Budijanto, "www.kemkes.go.id," Pusat Data dan Informasi Kementerian Kesehatan RI , 20 Oktober 2018. [Online]. Available: file:///D:/Download/Buletin-Stunting-2018.pdf. [Accessed 11 April 2020].

[5] N. N. Ariati, "Description of nutritional status and the incidence of stunting children in early childhood education programs in BaliIndonesia,", Bali Medical Journal (Bali Med J), vol. Volume 7, no. PISSN.2089-1180, E-ISSN.2302-2914, pp. 723-726, 2018.

[6] S. Dani, "https://aceh.tribunnews.com/," SerambiNews, 4 Maret 2019. [Online]. Available: https://aceh.tribunnews.com/2019/03/04/aceh-peringkat-tiga-stunting. [Accessed 11 April 2020].

[7] C. I. Damashinta, "Badan Pusat Statistik Kabupaten Boyolali," https://www.solopos.com/, 2 Desember 2018. [Online]. Available: https://www.solopos.com/sanitasi-indonesia-terburuk-ketiga-956428. [Accessed 11 April 2020].

[8] K. A. Levin, "Study design III: Cross-sectional studies," EvidenceBased Dentistry, vol. 7, DOI: 10.1038/sj.ebd.6400375, p. 24-25, 2006.

[9] M. E. H. a. J. A. Kaminsky, "Cultural preferences for the methods and motivation of sanitation infrastructure development," Journal of Water, Sanitation and Hygiene for Development, vol. 8, no. DOI: 10.2166/washdev.2017.188, pp. 1-10, 2017.

[10] D. S. Jeffrey Hammera, "Subdistrict sanitation and child health: Effects and external validity in a randomized field experiment in rural India," Journal of Health Economics, vol. 48, no. doi: 10.1016/j.jhealeco.2016.03.003, p. https: //www.ncbi.nlm.nih.gov/pmc/articles/PMC4920645/, 2016.

[11] Y. Afacan, "Public Toilets: An Exploratory Study on the Demands, Needs, and Expectations in Turkey," Environment and Planning B: Urban Analytics and City Science, vol. 42, no. https://doi.org/10.1068/b130020p,

https://journals.sagepub.com/doi/10.1068/b130020p, 2015.

[12] P. Vonaesch, "Factors associated with stunting in healthy children aged 5 years and less living in Bangui (RCA)," National Library of Medicine, vol. 12, no. doi: 10.1371/journal.pone.0182363, p. https://www.ncbi.nlm.nih.gov/pmc/articles/PMC5552116/, 2017. 